\title{
ANALISIS PENGARUH PENGGUNAAN JASA IKLAN RADIO TERHADAP TINGKAT PENDAPATAN USAHA (STUDI KASUS PADA PENGIKLAN DI OZ RADIO BANDA ACEH)
}

\author{
(Analysis of The Effect Using Radio As Advertising To The Level Of Business \\ Income (Case Study On Advertisers At OZ Radio Banda Aceh) \\ Arief Rachman Hakim ${ }^{1}$, Agus Nugroho ${ }^{1}$, Suyanti Kasimin ${ }^{1 *}$ \\ ${ }^{1}$ Program Studi Agribisnis, Fakultas Pertanian, Universitas Syiah Kuala
}

\begin{abstract}
Abstrak. Iklan tentu saja merupakan hal yang sangat penting untuk dilakukan oleh suatu usaha untuk meningkatkan kualitas dari usahanya. Banyak sekali media yang dapat digunakan untuk media beriklan dan salah satunya adalah radio, radio yang dianggap sudah mulai ditinggalkan justru merupakan salah satu media yang tepat dalam beriklan karena memiliki keunggulan tersendiri. Tujuan dari penelitian ini adalah untuk melihat adakah pengaruh beriklan diradio terhadap suatu usaha dan akan dilihat lewat pendapatan usaha itu sendiri. Model analisis yang digunakan adalah uji-t untuk melihat perbedaan atau pengaruh sebelum dan sesudah beriklan di radio sedangkan untuk metode yang digunakan adalah survey serta wawancara. Hasil dari penelitian ini menunjukan bahwa terdapat perubahan atau pengaruh yang signifikan terhadap pendapatan usaha sebelum dan sesudah menggunakan jasa iklan radio. Hal ini dibuktikan dengan kenaikan pendapatan terhadap 7 usaha yang diteliti yang mana usaha tersebut adalah pengiklan di OZ Radio Banda Aceh. Tentu saja 7 usaha tersebut memiliki persentase perubahan yang berbeda-beda yang mana hal tersebut dapat terjadi karena beberapa hal seperti waktu pemutaran, frekuensi, konsep iklan dan lain sebagainya.
\end{abstract}

Kata kunci: Iklan, Radio, Pendapatan Usaha, Pengaruh Iklan, Promosi.

\begin{abstract}
Advertising is a very important thing to be done by an effort to improve the quality of its business. There are so many media that can be used for advertising and one of them is radio, radio which is considered to have been abandoned is precisely one of the right media in advertising because it has its own advantages. The purpose of this study is to see whether there is an influence of advertising on a business and will be seen through the business income itself. The analysis model used is the t-test to see differences or influences before and after using advertising on the radio while the methods used are surveys and interviews. The results of this study indicate that there is a significant change or influence on business income before and after using radio advertising services. This is evidenced by the increase in income for the 7 businesses studied which are advertisers on OZ Radio Banda Aceh. Of course these 7 businesses have different percentage changes which can occur due to several things such as playback time, frequency, concept of advertising and so on..
\end{abstract}

Keywords: Advertising, Radio, Business Revenue, Advertising Influence, Promotion.

\section{PENDAHULUAN}

Iklan sebagai salah satu komponen penting dalam pemasaran yang mampu menarik perhatian terhadap suatu produk sebesar 79,40\% dan mendorong keinginan konsumen untuk berbelanja sebesar 65,60\%. Kotler (2001) menyatakan iklan sebagai bagian dari promosi mempunyai pengaruh yang sangat besar terhadap keberhasilan sebuah usaha dan akan meningkatkan kepercayaan dan kedekatan dengan konsumen (Boyd et all , 2000). 
Saat ini berbagai media dapat digunakan sebagai media iklan, seperti televisi, media cetak, media sosial, dan radio. Namun banyak anggapan bahwa radio sudah mulai ditinggalkan pendengarnya dan tidak memberikan dampak yang berarti. Padahal kenyataannya, radio masih menjadi salah satu media yang memiliki segmentasi pasar tertentu dan dapat diakses oleh penggunanya dengan sangat mudah. Berdasarkan suatu survey yang dilakukan oleh Nielsen (2016) menyatakan bahwa peranan radio sebagai informsi berada pada posisi keempat, yaitu 38\% setelah televisi (98\%), media cetak (52\%), dan internet (40\%). Bahkan jika dilihat dari segi kepercayaan konsumen, radio masih lebih memiliki kepercayaan lebih tinggi daripada iklan di sinema atau video online. Pendengar adalah orang yang paling penting dalam konteks komunikasi siaran (Ardiansyah, 2006), dan pendengar radio di era seperti sekarang sebenarnya adalah kaum milenial yang mengakses radio cukup dari smartphone nya saja.

Terlepas daripada televisi dan media cetak, radio merupakan alat promosi yang baik karena memiliki jangkauan pasar tersendiri yang penyampaian informasinya cepat dan tidak terbatas jarak (Wowor, 2013). Belum lagi radio di jaman sekarang sudah berevolusi, radio dapat diakses melalui aplikasi tertentu atau website yang tentu saja dapat diakses oleh seluruh pengguna internet di seluruh dunia. Untuk Kota Banda Aceh sendiri, terdapat kurang lebih 20 stasiun radio yang beroperasi dan salah satunya adalah OZ Radio Banda Aceh yang merupakan radio yang sudah 9 tahun beroperasi di Kota Banda Aceh.

Berbagai iklan komersial diputar disela-sela hiburan di radio, pemutaran iklan ini bahkan diputarkan berulang-ulang di sela-sela informasi atau bahkan dibacakan oleh penyiar radio itu sendiri. Hal ini akan menjadi salah satu senjata ampuh dalam penyampaian pesan untuk pendengar radio dan akan mengubah pola pikir dan rasa ingin tahu dari pendengar. Membangun theater of mind dari pendengar radio merupakan cara yang selalu digunakan pengiklan radio untuk menarik pendengar agar mau mencoba produk atau jasa yang ditawarkan dalam iklan tersebut. Berdasarkan survey Nielsen Radio Audience (2017) belanja iklan di radio di Indonesia sepanjang bulan Januari hingga Juli 2017 adalah 100 Milyar perbulannya. Angka ini cukup besar dan dapat dilihat bahwa iklan di radio masih menjadi salah satu teknik beriklan yang diperhitungkan dan memang iklan di radio yang justru bersifat lokal dan lucu yang menjadi daya tarik bagi pendengarnya.

Pengiklan di radio bisa saja berasal dari berbagai sektor, baik pengusaha di sektor kuliner, elektronik, perabot rumah tangga dan furniture, otomotif, fashion, sampai pada sektor pemerintahan, seperti dinas-dinas atau instansi-instansi yang menggunakan jasa iklan di radio untuk menyampaikan tujuan atau kegiatan kegiatan yang dilakukan.

Berdasarkan dari uraian diatas maka rumusan masalah yang dapat diambil adalah apakah ada pengaruh menggunakan jasa iklan radio sebagai media iklan terhadap pendapatan suatu usaha.

Tujuan dari penelitian ini adalah untuk melihat pengaruh dari penggunaan media radio sebagai jasa iklan, dan akan dilihat pengaruhnya terhadap pendapatan suatu usaha.

Analisis Pengaruh Penggunaan Jasa Iklan Radio Terhadap Tingkat Pendapatam Usaha 


\section{METODE PENELITIAN}

\section{Tempat dan Waktu Penelitian}

Penelitian ini dilakukan di Kota Banda Aceh, dengan perencanaan awal dilakukan pada bulan Januari 2018, namun waktu penelitian ini juga menyesuaikan dengan proses penyusunan dan bimbingan proposal penelitian yang dilakukan oleh peneliti. Sehingga waktu penelitian yang telah ditetapkan tidaklah mutlak, akan tetapi dapat berubah sesuai kondisi tertentu.

\section{Populasi dan Sampel}

Populasi merupakan gabungan dari seluruh elemen yang ada yang akan membentuk suatu peristiwa yang memiliki karakteristik yang sama yang nantinya akan menadi pusat perhatian peneliti karena hal tersebut dipandang sebagai sebuah semesta penelitian (Ferdinand, 2006). Populasi dalam penelitian ini adalah seluruh usaha-usaha di Kota Banda Aceh yang beriklan di Radio yang ada di Banda Aceh.

Sedangkan sampel adalah subset dari populasi, terdiri dari beberapa anggota populasi (Ferdinand, 2006). Sampel merupakan bagian dari populasi dan diteliti secara lebih rinci. Dalam penelitian ini, penarikan sampel menggunakan metode Purposive sampling, yaitu teknik penarikan sampel dengan tujuan yang mendasar. Sampel dalam penelitian ini adalah usaha yang ada di Kota Banda Aceh yang beriklan di OZ Radio Banda Aceh.

\section{Metode Analisis}

1. Analisis Pendapatan

Pada penelitian ini, dampak iklan di radio terhadap pendapatan usaha dapat dilihat dengan membandingkan pendapatan usaha sebelum menggunakan jasa iklan dengan pendapatan sesudah menggunakan jasa iklan di radio. Analisis ini digunakan untuk mengetahui sejauh mana pengaruh iklan atau promosi di radio terhadap pendapatan usaha yang ada di Kota Banda Aceh. Analisis pendapatan usaha dilakukan pada tahun/bulan, yaitu pada tahun/bulan sebelum beriklan di radio dan pada tahun/bulan sesudah beriklan di radio.

\section{Uji t (Uji Beda)}

Untuk mengetahui perbedaan pendapatan usaha sebelum menggunakan jasa iklan dengan pendapatan usaha setelah menggunakan jasa iklan, maka digunakan uji t sampel bebas (Independent Sample t Test) dengan rumus sebagai berikut :

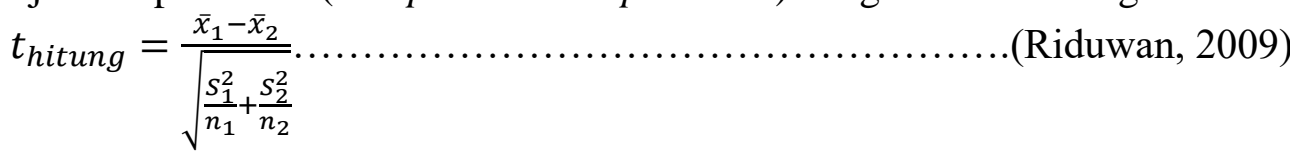

Dimana :

$\bar{x}_{1} \quad$ : Rata-Rata Pendapatan Usaha Sebelum Beriklan

$\bar{x}_{2} \quad$ : Rata-Rata Pendapatan Usaha Setelah Beriklan

$S_{1}^{2} \quad$ : Devisiasi Standar Pendapatan Usah Sebelum Beriklan

$S_{2}^{2} \quad$ : Devisiasi Standar Pendapatan Usaha Setelah Beriklan

$n_{1} \quad$ : Jumlah Bulan Yang Diambil Sebagai Sampel Sebelum Beriklan

$n_{2} \quad$ : Jumlah Bulan Yang Diambil Sebagai Sampel Setelah Beriklan

Analisis Pengaruh Penggunaan Jasa Iklan Radio Terhadap Tingkat Pendapatam Usaha 
Formulasi hipotesis sebagai berikut :

Ho : Pendapatan usaha sebelum menggunakan jasa iklan berbeda dibandingkan

pendapatan usaha setelah menggunakan jasa iklan

$\mathrm{Ha}$ : Pendapatan usaha sebelum menggunakan jasa iklan sama dibandingkan

pendapatan usaha setelah menggunakan jasa iklan

Dengan kriteria keputusan :

Jika $t_{\text {hitung }} \leq t_{\text {tabel }}$, maka terima Ho tolak Ha

Jika $t_{\text {hitung }}>t_{\text {tabel }}$, maka terima Ha tolak Ho

\section{Gambaran Umum}

\section{HASIL PENELITIAN DAN PEMBAHASAN}

Radio sudah mengalami perkembangan dari masa kemasa, di Kota Banda Aceh radio swasta berkembang cukup pesat pascastunami di tahun 2004. Sampai sekarang, untuk Kota Banda Aceh sendiri, terdapat kurang lebih 20 stasiun radio yang beroperasi dan salah satunya adalah OZ Radio Banda Aceh. Setiap radio memilki segmentasi yang berbeda-beda, mulai dari segmen pendengar usia 15-35 tahun yang biasa disebut contemporary dan juga pendengar yang ditargetkan untuk keluarga (all segment). Radio-radio ini hadir untuk meramaikan udara Kota Banda Aceh dengan berbagai program unggulan, musik, informasi, dan tentu saja iklan yang diputar di radio tersebut.

Iklan di radio di Kota Banda Aceh bervariasi mulai dari usaha-usaha makanan sampai keperluan pemerintahan. Iklan tersebut akan masuk melalui administrasi kemudian diteruskan ke bidang kreatif untuk penulisan naskah dan ide baru kemudian dilanjutkan ke bidang produksi untuk diproduksikan. Setelah mendapat persetujuan dari pengiklan barulah iklan tersebut bisa diputar dengan jadwal yang sudah ditentukan diawal kesepakatan.

Usaha yang beriklan di radio biasanya memiliki lama dan jumlah pemutaran yang berbeda-beda sesuai dengan budget yang dimiliki. Namun, pematokan terhadap harga iklan itu tersendiri juga dapat ditentukan berdasarkan kesepakatan antara pihak radio dengan calon pengiklan. Kenyataannya, tidak seluruhnya berbicara tentang uang, bisa saja pengiklan memberikan pembayaran, berupa barang atau kerja sama lainnya. Namun, kelihaian calon pengiklan dalam memilih di jam mana iklannya akan diputarkan dan berapa kali perhari akan diputarkan, akan sangat menentukan terhadap efektivitas dari iklan tersebut.

\section{Analisis Perbedaan Pendapatan Usaha Sebelum dan Sesudah Beriklan di Radio di Kota Banda Aceh}

Untuk mengetahui pengaruh iklan di radio di Kota Banda Aceh yang mana dalam hal ini terdapat 7 usaha yang dijadikan sampel dalam penelitian pengiklan di OZ Radio Banda Aceh, yaitu Obel Crab (Kuliner), Paper Melon (Interior), Banda Motor (Otomotif), Rocket (Clothing Line), Tanabata (Cafe and Coffee Shop), Istana Rame (Kuliner), Rawk Street (Cafe and Coffee Shop).

\section{Pendapatan Sebelum dan Sesudah Beriklan di Radio pada Usaha Kuliner (Obel Crab)}

Usaha ini merupakan salah satu usaha kuliner yang ada di Kota Banda Aceh, terletak di pusat Kota Banda Aceh, yaitu di Daerah Batoh, Lueng Bata. Obel Crab

Analisis Pengaruh Penggunaan Jasa Iklan Radio Terhadap Tingkat Pendapatam Usaha 
merupakan salah satu destinasi kuliner yang cukup dikenal oleh masyarakat Kota Banda Aceh. Obel Crab berdiri semenjak tahun 2015 dan mengambil pasar dari segala kalangan dan mengedepankan kepiting sebagai menu utama. Usaha ini beriklan di OZ Radio Banda Aceh pada bulan Januari tahun 016 dan mendapatan 5 kali jumlah pemutaran iklan setiap harinya. Berikut tingkat pendapatan usaha kuliner (Obel Crab) sebelum dan sesudah beriklan di OZ Radio Banda Aceh dapat dilihat pada Tabel 1 berikut ini.

Tabel 1. Tingkat Pendapatan Usaha Kuliner (Obel Crab) Sebelum dan Sesudah Beriklan di OZ Radio Banda Aceh (September 2015 - April 2016)

\begin{tabular}{llll}
\hline & & \multicolumn{2}{l}{ Pendapatan (Rp/Bulan) } \\
\cline { 3 - 4 } No. & Uraian & $\begin{array}{l}\text { Sebelum Beriklan di } \\
\text { OZ Radio Banda Aceh }\end{array}$ & $\begin{array}{l}\text { Sesudah } \\
\text { OZ Radio Banda Aceh }\end{array}$ \\
\hline 1. & September 2015 & 30.000 .000 & - \\
2. & Oktober 2015 & 31.100 .000 & - \\
3. & November 2015 & 28.900 .000 & - \\
4. $\quad$ Desember 2015 & 33.500 .000 & - \\
5. $\quad$ Januari 2016 & - & 40.800 .000 \\
6. $\quad$ Februari 2016 & - & 44.800 .000 \\
7. $\quad$ Maret 2016 & - & 42.850 .000 \\
8. April 2016 & - & 48.000 .000 \\
\hline Jumlah & $\mathbf{1 2 3 . 5 0 0 . 0 0 0}$ & $\mathbf{1 7 6 . 4 5 0 . 0 0 0}$ \\
Rata-Rata & $\mathbf{3 0 . 8 7 5 . 0 0 0}$ & $\mathbf{4 4 . 1 1 2 . 5 0 0}$ \\
Persentase $\quad$ Perubahan & $\mathbf{4 3 \%}$ & \\
(\%) & &
\end{tabular}

Sumber: Data Primer (Diolah), 2018

Berdasarkan Tabel 1 di atas menunjukkan rata-rata pendapatan usaha kuliner (Obel Crab) pada bulan September 2015 hingga Desember 2015 adalah sebesar Rp. 30.875.000, dimana pendapatan tersebut adalah pendapatan sebelum beriklan di OZ Radio Banda Aceh. Sedangkan rata-rata pendapatan pada bulan Januari 2016 hingga April 2016 adalah sebesar Rp. 44.112.500, dimana pendapatan tersebut adalah pendapatan sesudah beriklan di OZ Radio Banda Aceh. Hal ini dapat dilihat pada grafik pada gambar 2 di bawah ini.

Berdasarkan penjelasan di atas, maka hasil perbandingan $\overline{\mathrm{X}}_{1}<\overline{\mathrm{X}}_{2}$, dimana hasil perhitungan menggunakan statistik uji $t$ didapat nilai $t_{\text {hitung }}<t_{\text {tabel }}(-7<2,447)$ dengan derajat kebebasan $(\mathrm{df})=6$ dan taraf nyata $(\alpha)=0,05$, dengan demikian terima Ho tolak Ha, artinya terdapat perbedaan antara pendapatan usaha sebelum menggunakan jasa iklan di radio dengan setelah menggunakan jasa iklan di radio. Pendapatan usaha kuliner (Obel Crab) setelah beriklan di radio jauh lebih besar, dibandingkan sebelum beriklan di radio.

\section{Pendapatan Sebelum dan Sesudah Beriklan di Radio pada Usaha Interior (Paper Melon)}

Paper Melon merupakan salah satu usaha yang bergerak dibidang interior rumah, yaitu wallpaper. Usaha ini merupakan pusat wallpaper yang sudah sangat besar di Kota Banda Aceh, karena usaha wallpaper ini tergolong baru di Kota Banda Aceh khususnya. Saat ini Paper Melon sangat dicari oleh pemilik rumah yang baru direnovasi atau dibangun dan kantor-kantor yang menginginkan

Analisis Pengaruh Penggunaan Jasa Iklan Radio Terhadap Tingkat Pendapatam Usaha 446 (Studi Kasus Pada Pengiklan di OZ Radio Banda Aceh) Arief Rachman Hakim, Agus Nugroho, Suyanti Kasimin.

Jurnal Ilmiah Mahasiswa Pertanian Unsyiah, Vol.3, No.4 , November 2018: 442-455 
keindahan dan kenyamanan dalam kantornya. Letak toko yang strategis menjadikan Paper Melon sangat mudah untuk dicari. Usaha interior ini mulai beriklan di OZ Radio Banda Aceh pada bulan Juni 2016 dan September 2017, bahkan sampai 2018 dengan 3 kali penayangan setiap harinya. Berikut tingkat pendapatan usaha interior (Paper Melon) sebelum dan sesudah beriklan di OZ Radio Banda Aceh dapat dilihat pada Tabel 2 berikut ini.

Tabel 2. Tingkat Pendapatan Usaha Interior (Paper Melon) Sebelum dan Sesudah Beriklan di OZ Radio Banda Aceh (Mei 2017 - Desember 2017)

\begin{tabular}{|c|c|c|c|c|}
\hline \multirow{3}{*}{ No. } & \multirow{3}{*}{ Uraian } & \multicolumn{3}{|c|}{ Pendapatan (Rp/Bulan) } \\
\hline & & \multicolumn{2}{|c|}{ Sebelum Beriklan di } & \multirow{2}{*}{$\begin{array}{l}\text { Sesudah Beriklan di } \\
\text { OZ Radio Banda Aceh }\end{array}$} \\
\hline & & $\begin{array}{l}\text { OZ Radio } \\
\text { Aceh }\end{array}$ & Banda & \\
\hline 1. & Mei 2017 & 20.300 .000 & & - \\
\hline 2. & Juni 2017 & 23.435 .000 & & - \\
\hline 3. & Juli 2017 & 19.821 .000 & & - \\
\hline 4. & Agustus 2017 & 20.950 .000 & & - \\
\hline 5. & September 2017 & - & & 40.348 .000 \\
\hline 6. & Oktober 2017 & - & & 34.400 .000 \\
\hline 7. & November 2017 & - & & 35.650 .000 \\
\hline 8. & Desember 2017 & - & & 39.833 .000 \\
\hline \multicolumn{2}{|c|}{ Jumlah } & 84.506.000 & & 150.231 .000 \\
\hline \multicolumn{2}{|c|}{ Rata-Rata } & 21.126.500 & & 37.557.750 \\
\hline \multicolumn{2}{|c|}{$\begin{array}{l}\text { Persentase } \\
(\%)\end{array}$} & $78 \%$ & & \\
\hline
\end{tabular}

Sumber: Data Primer (Diolah), 2018

Berdasarkan Tabel 2 di atas menunjukkan rata-rata pendapatan usaha interior (Paper Melon) dari bulan Mei 2017 - Agustus 2017 adalah sebesar Rp. 21.126.500, dimana pendapatan tersebut adalah pendapatan sebelum beriklan di OZ Radio Banda Aceh. Sedangkan rata-rata pendapatan pada bulan September 2017 Desember 2017 adalah sebesar Rp. 37.557.750, dimana pendapatan tersebut adalah pendapatan sesudah beriklan di OZ Radio Banda Aceh.

Berdasarkan penjelasan di atas, maka hasil perbandingan $\bar{X}_{1}<\bar{X}_{2}$, dimana hasil perhitungan menggunakan statistik uji $\mathrm{t}$ didapat nilai $\mathrm{t}_{\text {hitung }}<\mathrm{t}_{\text {tabel }}(-9,716<$ $2,447)$ dengan derajat kebebasan $(\mathrm{df})=6$ dan taraf nyata $(\alpha)=0,05$, dengan demikian terima Ho tolak Ha, artinya terdapat perbedaan antara pendapatan usaha sebelum menggunakan jasa iklan di radio dengan setelah menggunakan jasa iklan di radio.

\section{Pendapatan Sebelum dan Sesudah Beriklan di Radio pada Usaha Otomotif (Banda Motor)}

Banda motor merupakan salah satu usaha yang bergerak di bidang otomotif dan aksesoris mobil dan merupakan salah satu yang terbaik di bidangnya. Banda motor telah berekspansi menjadi salah satu usaha lokal yang memiliki pasar yang cukup luas karena barang yang disediakan oleh usaha ini tergolong cukup lengkap dan untuk berbagai jenis mobil. Usaha ini beralamat di Jl. Twk. Mohd. Daudsyah, Peunayong, Kota Banda Aceh. Usaha otomotif (Banda Motor) ini sudah beriklan di OZ Radio Banda Aceh pada bulan Agustus 2016 hingga 2017 dengan 8 kali

Analisis Pengaruh Penggunaan Jasa Iklan Radio Terhadap Tingkat Pendapatam Usaha 447 (Studi Kasus Pada Pengiklan di OZ Radio Banda Aceh) Arief Rachman Hakim, Agus Nugroho, Suyanti Kasimin.

Jurnal Ilmiah Mahasiswa Pertanian Unsyiah, Vol.3, No.4 , November 2018: 442-455 
pemutaran perharinya. Berikut tingkat pendapatan usaha otomotif (Banda Motor) sebelum dan sesudah beriklan di OZ Radio Banda Aceh dapat dilihat pada Tabel 3 berikut ini.

Tabel 3. Tingkat Pendapatan Usaha Otomotif (Banda Motor) Sebelum dan Sesudah Beriklan di OZ Radio Banda Aceh (September 2016 - April 2017)

\begin{tabular}{|c|c|c|c|}
\hline \multirow[b]{2}{*}{ No. } & \multirow[b]{2}{*}{ Uraian } & \multicolumn{2}{|l|}{ Pendapatan (Rp/Bulan) } \\
\hline & & $\begin{array}{l}\text { Sebelum Beriklan di } \\
\text { OZ Radio Banda Aceh }\end{array}$ & $\begin{array}{l}\text { Sesudah Beriklan di } \\
\text { OZ Radio Banda Aceh }\end{array}$ \\
\hline 1. & September 2016 & 39.800 .000 & - \\
\hline 2. & Oktober 2016 & 35.920 .000 & - \\
\hline 3. & November 2016 & 41.070 .000 & - \\
\hline 4. & Desember 2016 & 42.955 .000 & - \\
\hline 5. & Januari 2017 & - & 59.980 .000 \\
\hline 6. & Februari 2017 & - & 69.250 .000 \\
\hline 7. & Maret 2017 & - & 66.955 .000 \\
\hline 8. & April 2017 & - & 65.100 .000 \\
\hline \multicolumn{2}{|c|}{ Jumlah } & 159.745.000 & 261.285 .000 \\
\hline \multicolumn{2}{|c|}{ Rata-Rata } & 39.936 .250 & 65.321 .250 \\
\hline \multicolumn{2}{|c|}{$\begin{array}{l}\text { Persentase } \\
(\%)\end{array}$} & $64 \%$ & \\
\hline
\end{tabular}

Sumber: Data Primer (Diolah), 2018

Berdasarkan Tabel 3 di atas menunjukkan rata-rata pendapatan usaha otomotif (Banda Motor) dari bulan September 2017 - Desember 2017 adalah sebesar Rp. 39.936.250, dimana pendapatan tersebut adalah pendapatan sebelum beriklan di OZ Radio Banda Aceh. Sedangkan rata-rata pendapatan pada bulan Januari 2017 - April 2017 adalah sebesar Rp. 65.321.250, dimana pendapatan tersebut adalah pendapatan sesudah beriklan di OZ Radio Banda Aceh.

Berdasarkan penjelasan di atas, maka hasil perbandingan $\overline{\mathrm{X}}_{1}<\overline{\mathrm{X}}_{2}$, dimana hasil perhitungan menggunakan statistik uji $\mathrm{t}$ didapat nilai $\mathrm{t}_{\text {hitung }}<\mathrm{t}_{\text {tabel }}(-10,276<$ $2,447)$ dengan derajat kebebasan $(\mathrm{df})=6$ dan taraf nyata $(\alpha)=0,05$, dengan demikian terima Ho tolak Ha, artinya terdapat perbedaan antara pendapatan usaha sebelum menggunakan jasa iklan di radio dengan setelah menggunakan jasa iklan di radio.

\section{Pendapatan Sebelum dan Sesudah Beriklan di Radio pada Usaha Clothing Line (Rocket)}

Rocket merupakan salah satu brand clothing lokal yang juga menargetkan pasar anak muda yang ada di Kota Banda Aceh. Brand lokal ini merupakan salah satu brand yang memiliki identitas yang cukup baik di kalangan anak muda dan mampu memiliki toko atau store sendiri yang terletak di Jl. T.P Nyak Makam, Lampineung, Kota Banda Aceh. Nama Rocket sendiri sebenarnya tidak hanya sebatas lingkaran Kota Banda Aceh. Rozi sebagai pemilik Rocket juga menitipkan barangnya di store-store lain yang ada di luar Kota Banda Aceh, seperti di Lhokseumawe, Langsa, dsb. Brand lokal ini sudah beriklan di OZ Radio Banda Aceh sejak bulan April 2016 dengan iklan yang diputarkan 5 kali perharinya.

Analisis Pengaruh Penggunaan Jasa Iklan Radio Terhadap Tingkat Pendapatam Usaha 448 (Studi Kasus Pada Pengiklan di OZ Radio Banda Aceh) Arief Rachman Hakim, Agus Nugroho, Suyanti Kasimin.

Jurnal Ilmiah Mahasiswa Pertanian Unsyiah, Vol.3, No.4 , November 2018: 442-455 
Berikut tingkat pendapatan usaha clothing line (Rocket) sebelum dan sesudah beriklan di OZ Radio Banda Aceh dapat dilihat pada Tabel 4 berikut ini.

Tabel 4. Tingkat Pendapatan Usaha Clothing Line (Rocket) Sebelum dan Sesudah Beriklan di OZ Radio Banda Aceh (Desember 2016 - Juli 2017)

\begin{tabular}{|c|c|c|c|c|}
\hline \multirow{4}{*}{ No. } & \multirow{4}{*}{ Uraian } & \multicolumn{3}{|c|}{ Pendapatan (Rp/Bulan) } \\
\hline & & \multirow{3}{*}{\multicolumn{2}{|c|}{$\begin{array}{l}\text { Sebelum } \text { Beriklan di } \\
\text { OZ Radio Banda } \\
\text { Aceh }\end{array}$}} & \multirow{3}{*}{$\begin{array}{l}\text { Sesudah Beriklan di } \\
\text { OZ Radio Banda Aceh }\end{array}$} \\
\hline & & & & \\
\hline & & & & \\
\hline 1. & Desember 2015 & 12.450 .000 & & - \\
\hline 2. & Januari 2016 & 15.300 .000 & & - \\
\hline 3. & Februari 2016 & 13.750 .000 & & - \\
\hline 4. & Maret 2016 & 11.980 .000 & & - \\
\hline 5. & April 2016 & - & & 22.650 .000 \\
\hline 6. & Mei 2016 & - & & 21.050 .000 \\
\hline 7. & Juni 2016 & - & & 33.800 .000 \\
\hline 8. & Juli 2016 & - & & 40.010 .000 \\
\hline \multicolumn{2}{|c|}{ Jumlah } & 53.480 .000 & & 117.510.000 \\
\hline \multicolumn{2}{|c|}{ Rata-Rata } & 13.370.000 & & 29.377.500 \\
\hline \multicolumn{2}{|c|}{$\begin{array}{l}\text { Persentase } \\
(\%)\end{array}$} & $119 \%$ & & \\
\hline
\end{tabular}

Sumber: Data Primer (Diolah), 2018

Berdasarkan Tabel 4 di atas menunjukkan rata-rata pendapatan usaha clothing line (Rocket) dari bulan Desember 2015 - Maret 2016 adalah sebesar Rp. 13.370.000, dimana pendapatan tersebut adalah pendapatan sebelum beriklan di OZ Radio Banda Aceh. Sedangkan rata-rata pendapatan pada bulan April 2016 - Juli 2016 adalah sebesar Rp. 29.377.500, dimana pendapatan tersebut adalah pendapatan sesudah beriklan di OZ Radio Banda Aceh.

Berdasarkan penjelasan di atas, maka hasil perbandingan $\overline{\mathrm{X}}_{1}<\overline{\mathrm{X}}_{2}$, dimana hasil perhitungan menggunakan statistik uji $t$ didapat nilai $t_{\text {hitung }}<t_{\text {tabel }}(-3,480<$ $2,447)$ dengan derajat kebebasan $(\mathrm{df})=6$ dan taraf nyata $(\alpha)=0,05$, dengan demikian terima Ho tolak Ha, artinya terdapat perbedaan antara pendapatan usaha sebelum menggunakan jasa iklan di radio dengan setelah menggunakan jasa iklan di radio.

\section{Pendapatan Sebelum dan Sesudah Beriklan di Radio pada Usaha Cafe and Coffee Shop (Tanabata)}

Tanabata merupakan salah satu warung kopi terbaik di Kota Banda Aceh yang menargetkan semua kalangan untuk menjadi konsumen mereka. Tanabata memiliki kopi yang enak dan juga menjadi salah satu dari beberapa warung kopi arabica pertama di Kota Banda Aceh. Selain kopi yang menjadi senjata mereka, suasana yang nyaman dan memiliki working space adalah kelebihan dari Tanabata yang membuat banyak orang yang mempertimbangkan tempat ini sebagai tempat untuk mengerjakan tugas-tugas kantor ataupun tugas kuliah. Tanabata bekerja sama dengan OZ Radio Banda Aceh pada bulan Mei 2016 dengan 5 pemutaran iklan

Analisis Pengaruh Penggunaan Jasa Iklan Radio Terhadap Tingkat Pendapatam Usaha 449 (Studi Kasus Pada Pengiklan di OZ Radio Banda Aceh) Arief Rachman Hakim, Agus Nugroho, Suyanti Kasimin.

Jurnal Ilmiah Mahasiswa Pertanian Unsyiah, Vol.3, No.4 , November 2018: 442-455 
perharinya. Berikut tingkat pendapatan usaha cafe and coffe shop (Tanabata) sebelum dan sesudah beriklan di OZ Radio Banda Aceh dapat dilihat pada Tabel 5. Tabel 5. Tingkat Pendapatan Usaha Cafe and Coffe Shop (Tanabata) Sebelum dan Sesudah Beriklan di OZ Radio Banda Aceh (Januari 2016 - Agustus 2016)

\begin{tabular}{llll}
\hline & & \multicolumn{2}{l}{ Pendapatan (Rp/Bulan) } \\
\cline { 3 - 4 } No. & Uraian & $\begin{array}{l}\text { Sebelum Beriklan di } \\
\text { OZ Radio Banda Aceh }\end{array}$ & $\begin{array}{l}\text { Sesudah } \\
\text { OZ Radio Banda Aceh }\end{array}$ \\
\hline 1. & Januari 2016 & 44.850 .000 & - \\
2. & Februari 2016 & 48.700 .000 & - \\
3. $\quad$ Maret 2016 & 43.980 .000 & - \\
4. April 2016 & 51.120 .000 & - \\
5. $\quad$ Mei 2016 & - & 72.895 .000 \\
6. Juni 2016 & - & 68.950 .000 \\
7. Juli 2016 & - & 64.055 .000 \\
8. Agustus 2016 & - & 80.100 .000 \\
\hline Jumlah & $\mathbf{1 8 8 . 6 5 0 . 0 0 0}$ & $\mathbf{2 8 6 . 0 0 0 . 0 0 0}$ \\
Rata-Rata & $\mathbf{4 7 . 1 6 2 . 5 0 0}$ & $\mathbf{7 1 . 5 0 0 . 0 0 0}$ \\
Persentase $\quad$ Perubahan & $\mathbf{5 2 \%}$ & \\
(\%) & &
\end{tabular}

Sumber: Data Primer (Diolah), 2018

Berdasarkan Tabel 5 di atas menunjukkan rata-rata pendapatan usaha Cafe and Coffe Shop (Tanabata) dari bulan Januari 2016 - April 2016 adalah sebesar Rp. 41.162.500, dimana pendapatan tersebut adalah pendapatan sebelum beriklan di OZ Radio Banda Aceh. Sedangkan rata-rata pendapatan pada bulan Mei 2016 - Agustus 2016 adalah sebesar Rp. 71.500.000, dimana pendapatan tersebut adalah pendapatan sesudah beriklan di OZ Radio Banda Aceh.

Berdasarkan penjelasan di atas, maka hasil perbandingan $\overline{\mathrm{X}}_{1}<\overline{\mathrm{X}}_{2}$, dimana hasil perhitungan menggunakan statistik uji $t$ didapat nilai $t_{\text {hitung }}<t_{\text {tabel }}(-6,441<$ $2,447)$ dengan derajat kebebasan $(\mathrm{df})=6$ dan taraf nyata $(\alpha)=0,05$, dengan demikian terima Ho tolak Ha, artinya terdapat perbedaan antara pendapatan usaha sebelum menggunakan jasa iklan di radio dengan setelah menggunakan jasa iklan di radio.

\section{Pendapatan Sebelum dan Sesudah Beriklan di Radio pada Usaha Kuliner (Istana Rame)}

Istana rame merupakan usaha kuliner yang dicintai oleh semua kalangan, karena memiliki harga yang cukup murah dan memiliki menu makanan yang cukup variatif. Usaha ini juga terbilang cukup strategis, karena terletak di Jl. T. P. Nyak Makam, Lampineug, Kota Banda Aceh. Istana rame sendiri mengedepankan nasi uduk sebagai menu utama dan berbagai macam menu lainnya sebagai menu tambahan. Istana rame beriklan di OZ Radio Banda Aceh pada bulan Januari 2016 dan terus berlanjut sampai dengan tahun 2017 dengan 6 kali pemutaran iklan perharinya. Berikut tingkat pendapatan usaha Cafe and Coffe Shop (Tanabata) sebelum dan sesudah beriklan di OZ Radio Banda Aceh dapat dilihat pada Tabel 6 berikut ini.

Analisis Pengaruh Penggunaan Jasa Iklan Radio Terhadap Tingkat Pendapatam Usaha 
Tabel 6. Tingkat Pendapatan Usaha Kuliner (Istana Rame) Sebelum dan Sesudah Beriklan di OZ Radio Banda Aceh (Februari 2017 - September 2017)

\begin{tabular}{llll}
\hline & & \multicolumn{2}{l}{ Pendapatan (Rp/Bulan) } \\
\cline { 3 - 4 } No. & Uraian & $\begin{array}{l}\text { Sebelum Beriklan di } \\
\text { OZ Radio Banda Aceh }\end{array}$ & $\begin{array}{l}\text { Sesudah Beriklan di } \\
\text { OZ Radio Banda Aceh }\end{array}$ \\
\hline 1. & Februari 2017 & 33.650 .000 & - \\
2. & Maret2017 & 39.400 .000 & - \\
3. $\quad$ April 2017 & 37.810 .000 & - \\
4. $\quad$ Mei 2017 & 40.260 .000 & - \\
5. Juni 2017 & - & 50.385 .000 \\
6. Juli 2017 & - & 54.523 .000 \\
7. Agustus 2017 & - & 45.895 .000 \\
8. September 2017 & - & 51.600 .000 \\
\hline Jumlah & $\mathbf{1 5 1 . 1 2 0 . 0 0 0}$ & $\mathbf{2 0 2 . 4 0 3 . 0 0 0}$ \\
$\begin{array}{l}\text { Rata-Rata } \\
\text { Persentase } \quad \text { Perubahan } \\
\text { (\%) }\end{array}$ & $\mathbf{3 3 \%}$ & $\mathbf{5 0 . 6 0 0 . 7 5 0}$ \\
\hline
\end{tabular}

Sumber: Data Primer (Diolah), 2018

Berdasarkan Tabel 6 di atas menunjukkan rata-rata pendapatan usaha kuliner (Istana Rame) dari bulan Februari 2017 - Mei 2017 adalah sebesar Rp. 37.780.000, dimana pendapatan tersebut adalah pendapatan sebelum beriklan di OZ Radio Banda Aceh. Sedangkan rata-rata pendapatan pada bulan Juni 2017 - September 2017 adalah sebesar Rp. 50.600.750, dimana pendapatan tersebut adalah pendapatan sesudah beriklan di OZ Radio Banda Aceh.

Berdasarkan penjelasan di atas, maka hasil perbandingan $\bar{X}_{1}<\bar{X}_{2}$, dimana hasil perhitungan menggunakan statistik uji $\mathrm{t}$ didapat nilai $\mathrm{t}_{\text {hitung }}<\mathrm{t}_{\text {tabel }}(-5,534<$ $2,447)$ dengan derajat kebebasan $(\mathrm{df})=6$ dan taraf nyata $(\alpha)=0,05$, dengan demikian terima Ho tolak Ha, artinya terdapat perbedaan antara pendapatan usaha sebelum menggunakan jasa iklan di radio dengan setelah menggunakan jasa iklan di radio.

\section{Pendapatan Sebelum dan Sesudah Beriklan di Radio pada Usaha Cafe and Coffe Shop (Rawk Street)}

Rawk Street merupakan salah satu usaha yang berfokus pada jajanan kekinian yang menargetkan anak muda sebagai pangsa pasarnya. Usaha yang bergerak di bidang kuliner, memiliki menu andalan, yakni mie instant yang diolah dengan berbagai macam dan dicampur dengan berbagai bumbu. Dengan menu utama seperti itu, maka tidak sulit untuk Rawk Street untuk menarik pasar anak muda karena pada dasarnya menu tersebut sangat familiar di kalangan anak muda, selain juga karena usaha ini terletak di kawasan yang sangat strategis, yaitu di Jl. T. P. Nyak Makam, Lampineung, Kota Banda Aceh. Rawk Street bekerja sama dengan OZ Radio Banda Aceh pada bulan Februari 2016 dengan 5 kali penayangan setiap harinya. Berikut tingkat pendapatan usaha Cafe and Coffe Shop (Rawk Street) sebelum dan sesudah beriklan di OZ Radio Banda Aceh dapat dilihat pada Tabel 7 berikut ini. 
Tabel 7. Tingkat Pendapatan Usaha Cafe and Coffe Shop (Rawk Street) Sebelum dan Sesudah Beriklan di OZ Radio Banda Aceh (September 2015 - April 2016)

\begin{tabular}{llll}
\hline & & \multicolumn{2}{l}{ Pendapatan (Rp/Bulan) } \\
\cline { 3 - 4 } No. & Uraian & $\begin{array}{l}\text { Sebelum Beriklan di } \\
\text { OZ Radio Banda } \\
\text { Aceh }\end{array}$ & $\begin{array}{l}\text { Sesudah Beriklan di } \\
\text { OZ Radio Banda Aceh }\end{array}$ \\
\hline 1. & September 2015 & 12.660 .000 & - \\
2. & Oktober 2015 & 12.800 .000 & - \\
3. $\quad$ November 2015 & 16.050 .000 & - \\
4. $\quad$ Desember 2015 & 14.830 .000 & - \\
5. Januari 2016 & - & 25.725 .000 \\
6. $\quad$ Februari 2016 & - & 19.880 .000 \\
7. $\quad$ Maret 2016 & - & 23.100 .000 \\
8. April 2016 & - & 20.225 .000 \\
\hline Jumlah & $\mathbf{5 6 . 3 4 0 . 0 0 0}$ & $\mathbf{8 8 . 9 3 0 . 0 0 0}$ \\
Rata-Rata & $\mathbf{1 4 . 0 8 5 . 0 0 0}$ & $\mathbf{2 2 . 2 3 2 . 5 0 0}$ \\
Persentase $\quad$ Perubahan & $\mathbf{5 9 \%}$ & \\
(\%) & &
\end{tabular}

Sumber: Data Primer (Diolah), 2018

Berdasarkan Tabel 7 di atas menunjukkan rata-rata pendapatan usaha cafe and coffe shop (Rawk Street) dari bulan September 2015 - Desember 2015 adalah sebesar Rp. 14.085.000, dimana pendapatan tersebut adalah pendapatan sebelum beriklan di OZ Radio Banda Aceh. Sedangkan rata-rata pendapatan pada bulan Januari 2016 - April 2016 adalah sebesar Rp. 22.232.500, dimana pendapatan tersebut adalah pendapatan sesudah beriklan di OZ Radio Banda Aceh. Hal ini dapat dilihat pada grafik pada gambar 8 di bawah ini.

sesudah beriklan.

Berdasarkan penjelasan di atas, maka hasil perbandingan $\overline{\mathrm{X}}_{1}<\overline{\mathrm{X}}_{2}$, dimana hasil perhitungan menggunakan statistik uji $t$ didapat nilai $t_{\text {hitung }}<t_{\text {tabel }}(-5,101<2,447)$ dengan derajat kebebasan $(\mathrm{df})=6$ dan taraf nyata $(\alpha)=0,05$, dengan demikian terima Ho tolak Ha, artinya terdapat perbedaan antara pendapatan usaha sebelum menggunakan jasa iklan di radio dengan setelah menggunakan jasa iklan di radio.

\section{Perbandingan Pendapatan Usaha Sebelum dan Sesudah Beriklan di Radio di Kota Banda Aceh}

Adapun perbandingan pendapatan usaha sebelum dan sesudah beriklan di OZ Radio Banda Aceh dapat dilihat pada Tabel 8.

Berdasarkan Tabel 8 maka dapat disimpulkan bahwa jenis usaha cloting line atau fashion merupakan jenis usaha yang mendapatkan efek paling besar dari beriklan di radio. Pada persentase perubahan sebesar $119 \%$ memberikan arti bahwa terjadinya peningkatan yang melebihi rata-rata yang didapatkan usaha clothing line (Rocket) sesudah beriklan di OZ Radio Banda Aceh. Sedangkan pada usaha kuliner yang merupakan usaha yang mendapatkan persentase perubahan paling sedikit sebesar 33\%, yaitu pada usaha kuliner (Istana Rame). Hal ini terjadi dikarenakan

Analisis Pengaruh Penggunaan Jasa Iklan Radio Terhadap Tingkat Pendapatam Usaha 452 (Studi Kasus Pada Pengiklan di OZ Radio Banda Aceh) Arief Rachman Hakim, Agus Nugroho, Suyanti Kasimin.

Jurnal Ilmiah Mahasiswa Pertanian Unsyiah, Vol.3, No.4 , November 2018: 442-455 
beberapa hal, seperti waktu beriklan yang tepat dan pemutaran iklan dengan jumlah dan waktu yang tepat.

Tabel 8. Perbandingan Pendapatan Usaha Sebelum dan Sesudah Beriklan di Radio di Kota Banda Aceh, Tahun 2018

\begin{tabular}{|c|c|c|c|c|}
\hline \multirow[b]{2}{*}{ No. } & \multirow[b]{2}{*}{ Uraian } & \multicolumn{2}{|c|}{ Pendapatan (Rp/Bulan) } & \multirow[b]{2}{*}{$\begin{array}{l}\text { Persentase } \\
\text { Perubahan } \\
\quad(\%)\end{array}$} \\
\hline & & $\begin{array}{c}\text { Sebelum Beriklan di } \\
\text { OZ Radio Banda } \\
\text { Aceh }\end{array}$ & $\begin{array}{l}\text { Sesudah Beriklan di } \\
\text { OZ Radio Banda } \\
\text { Aceh }\end{array}$ & \\
\hline 1. & Obel Crab (Kuliner) & 30.875 .000 & 44.112 .500 & $43 \%$ \\
\hline 2. & Paper Melon (Interior) & 21.126 .500 & 37.557 .750 & $78 \%$ \\
\hline 3. & $\begin{array}{l}\text { Banda } \\
\text { (Otomotif) }\end{array}$ & 39.936 .250 & 65.321 .250 & $64 \%$ \\
\hline 4. & Rocket (Clothing Line) & 13.370 .000 & 29.377 .500 & $119 \%$ \\
\hline 5. & $\begin{array}{l}\text { Tanabata Coffee (Café } \\
\text { and Coffe Shop) }\end{array}$ & 47.162 .500 & 71.500 .000 & $52 \%$ \\
\hline 6. & Istana Rame (Kuliner) & 37.780 .000 & 50.600 .750 & $33 \%$ \\
\hline 7. & $\begin{array}{l}\text { Rawk Street (Café and } \\
\text { Coffe Shop) }\end{array}$ & 14.085 .000 & 22.232 .500 & $59 \%$ \\
\hline \multirow{2}{*}{\multicolumn{2}{|c|}{$\begin{array}{l}\text { Jumlah } \\
\text { Rata-Rata }\end{array}$}} & 204.335 .250 & 320.702 .250 & $448 \%$ \\
\hline & & 29.190 .750 & 45.814.607 & $64 \%$ \\
\hline
\end{tabular}

Sumber: Data Primer (Diolah), 2018

Pemutaran iklan sendiri terbagi menjadi waktu utama dengan kemungkinan pendengar lebih besar dan waktu biasa dengan kemungkinan pendengar lebih kecil atau biasa disebut prime time dan reguler time. Prime time radio berada di jam 07.00-09.00 WIB, 16.00-18.00 WIB, dan 20.00-23.00 WIB dan jam selebihnya adalah reguler time. Biasanya dalam beriklan, pengiklan yang mendapatkan prime time lebih banyak akan dikenakan biaya yang lebih besar juga namun tentu saja juga melihat jumlah atau frekuensi dari pemutaran tersebut dan faktor-faktor lain. Berikut biaya iklan yang dikeluarkan oleh usaha-usaha yang diteliti oleh peneliti beserta frekuensi pemutaran iklan di OZ Radio Banda Aceh dapat dilihat pada Tabel 9 berikut.

Tabel 9. Biaya Iklan dan Frekuensi Pemutaran Iklan di OZ Radio Banda, Tahun 2018

\begin{tabular}{llllll}
\hline \multirow{2}{*}{ No. } & \multicolumn{1}{c}{ Uraian } & \multirow{2}{*}{$\begin{array}{c}\text { Biaya Iklan } \\
(\mathbf{R p})\end{array}$} & $\begin{array}{c}\text { Prime } \\
\text { Time }\end{array}$ & $\begin{array}{c}\text { Regular } \\
\text { Time }\end{array}$ & $\begin{array}{c}\text { Persentase } \\
\text { Perubahan } \\
(\%)\end{array}$ \\
\hline 1. & Obel Crab (Kuliner) & 1.000 .000 & 3 & 3 & $43 \%$ \\
2. & Paper Melon (Interior) & 500.000 & 3 & 0 & $78 \%$ \\
3. & Banda Motor (Otomotif) & 1.000 .000 & 3 & 5 & $64 \%$ \\
4. $\quad$ Rocket (Clothing Line) & 1.250 .000 & 5 & 0 & $119 \%$ \\
5. $\quad$ Tanabata Coffee (Café and & 1.500 .000 & 5 & 2 & $52 \%$ \\
6. Coffe Shop) & Istana Rame (Kuliner) & 800.000 & 3 & 3 & $33 \%$ \\
7. Rawk Street (Café and Coffe & 800.000 & 4 & 0 & $59 \%$ \\
\hline Jumlah & Shop) & $\mathbf{6 . 8 5 0 . 0 0 0}$ & & & $\mathbf{4 4 8 \%}$ \\
Rata-Rata & $\mathbf{9 7 8 . 5 7 1}$ & & & $\mathbf{6 4 \%}$ \\
\hline
\end{tabular}

Sumber: Data Primer (Diolah), 2018

Berdasarkan Tabel 9 di atas menunjukkan bahwa usaha Rocket (Clothing Line) merupakan usaha yang mendapatkan efek paling besar (119\%) dengan biaya

Analisis Pengaruh Penggunaan Jasa Iklan Radio Terhadap Tingkat Pendapatam Usaha 
iklan Rp. 1.250.000 dan frekuensi pemutaran 5 kali perhari dan kelimanya di waktu prime time dan yang mendapatkan efek paling kecil $(43 \%)$ adalah usaha Istana Rame (Kuliner) dengan biaya iklan Rp. 800.000 dengan frekuensi 6 kali perhari dengan 3 prime time dan 3 reguler time.

Faktor lain yang bisa membuat perbedaan pada peningkatan pendapatan usaha-usaha tersebut adalah tergantung pada konsep iklan itu sendiri. Biasanya, iklan yang lucu dan kekinian yang biasa cepat ditangkap oleh pendengar sebagai calon konsumen. Namun iklan dengan konsep tegas dan lugas juga merupakan salah satu konsep yang unik dengan maksud dan tujuan yang jelas. Konsep dari iklan itu sendiri biasanya bisa berasal dari usaha-usaha tersebut sebagai client di radio atau memang sudah dipercayakan kepada radio tersebut untuk mengkonsepkan iklan itu sendiri.

Perpaduan dari bagaimana penyajian iklan tersebut atau berupa konsep iklan dan kapan waktu yang tepat iklan itu diputar merupakan faktor kesuksesan iklan tersebut walaupun terdapat faktor lain, seperti target pasar yang tepat, informasi yang disampaikan, dan lainnya. Namun tetap saja, seperti mana hasil dari penelitian ini, beriklan di radio tetap memberikan dampak positif terhadap suatu usaha dengan pengaruh yang berbeda-beda tentunya.

\section{Simpulan}

\section{SIMPULAN DAN SARAN}

Berdasarkan hasil penelitian dan pembahasan serta pengujian statistik pada penelitian ini, maka dapat ditarik simpulan bahwa :

1. Adanya peningkatan pendapatan pada usaha setelah menggunakan jasa iklan di radio, hal ini dibuktikan dengan meningkatnya pendapatan di seluruh usaha yang diteliti yang diteliti.

2. Pengaruh iklan paling besar didapatkan oleh usaha Rocket yang merupakan jenis usaha fashion/clothing line. Hal ini dapat dilihat dari peningkatan pendapatan usaha ini, pendapatan rata-rata sebelum beriklan di OZ Radio Banda Aceh adalah sebesar Rp. 13.370.000 dan pendapatan rata-rata setelah beriklan di OZ Radio Banda Aceh adalah sebesar Rp. 29.377.500, dengan persentase peningkatan adalah sebesar $119 \%$ dan dengan hasil perhitungan menggunakan statistik uji $t$, dimana $t_{\text {hitung }}<t_{\text {tabel }}(-3,480<2,447)$ dengan derajat kebebasan $(\mathrm{df})=6$ dan taraf nyata $(\alpha)=0,05$, dengan demikian terima Ho tolak Ha, yaitu terdapat perbedaan antara pendapatan usaha sebelum menggunakan jasa iklan di radio dengan setelah menggunakan jasa iklan di radio.

\section{Saran}

Untuk meningkatkan pendapatan, suatu usaha sangat disarankan untuk mengenalkan secara lebih baik dan lebih luas lagi usahanya kepada konsumen. Salah satu cara yang dapat dilakukan adalah menggunakan jasa iklan di radio sebagai media promosi dari usaha tersebut. Selain itu usaha tersebut juga disarankan untuk memilih waktu yang tepat dalam beriklan dan mempertimbangkan frekuensi pemutaran iklan agar mendapatkan hasil yang maksimal.

\section{DAFTAR PUSTAKA}

Analisis Pengaruh Penggunaan Jasa Iklan Radio Terhadap Tingkat Pendapatam Usaha 
Alifah, Siti. 2013. Media Iklan Dalam Era Radio 2.0. Universitas Gadjah Mada. Yogyakarta

Alma, B. 2008. Pengantar Bisnis. Alfabeta, Bandung.

Ardianto, Elvinaro. 2004. Komunikasi Massa Suatu Pengantar. Simbiosa Rekatama Media. Bandung

Arikunto, Suharsimi. 1998. Prosuder Penelitian Suatu Pendekatan Praktek. PT. Rineka Cipta. Jakarta.

Augusty, Ferdinand. 2006. Metode Penelitian Manajemen: Pedoman Penelitian untuk skripsi. Tesis dan Disertai Ilmu Manajemen. Semarang: Universitas Diponegoro.

Boyd, Harper W,Orville C. Walker dan Jean-Claude Larreche. 2000. Manajemen Pemasaran. Terjemahan Imam Nurmawan, S.E . Erlangga, Jakarta.

Christiana, W, Jessica. 2013. Pengaruh Iklan Komersial Radio Terhadap Perilaku Konsumtif Masyarakat Kelurahan Bahu Kota Manado.

Darmadi. D. 2013. Pengaruh promosi penjualan terhadap penjualan (studi kasus pt. Astra internasional tbk-tso cabang soetoyo malang). Jurnal: Vol 2. No 3. Fakultas Ilmu Administrasi Universitas Brawijaya, Malang.

Elvinaro, A. 2004. Komunikasi massa suatu pengantar. Simbiosa Rekatama Media, Jakarta.

Harley, P. 2005. Radio suatu pengantar untuk wacana dan praktik penyiaran. Bayumedia Publishing, Malang.

Lupiyoadi, R. 2006. Manajemen Pemasaran Jasa. Salemba Empat, Jakarta.

Masduki, 2005. Menjadi Broadcaster Profesional. Pustaka Populer LKIS, Yogyakarta.

Morissan, M. A. 2008. Jurnalistik Televisi Mutakhir, Media Grafika, Jakarta.

Morissan, 2009. Media penyiaran: Strategi Mengelola Radio dan Televisi. Prenada Media Group, Jakarta.

Nielsen Radio Audience Measurement. 2016. Survey Penetrasi Iklan.

Prayudha, Harley.2005. Radio Suatu Pengantar untuk Wacana, dan Praktik Penyiaran. Bayumedia. Malang.

Rahanatha, Bayu. 2008.Skema Pembentukan Positioning Terhadap Pendengar Dari Sebuah Stasiun Radio. Jakarta.

Reksoprayitno, 2004. Sistem Ekonomi dan Demokrasi Ekonomi. Bina Grafika. Jakarta.

Romli, A., S., M. 2004. Brodcast Jurnalism panduan menjadi penyiar, reporter, scriptwriter. Nuansa, Bandung.

Riduwan. 2009. Metode dan Teknik Menyusun Tesis. Alfabeta. Bandung.

Silalahi Ulber. 2005. Metode Penelitian Sosial. Unpar Press. Bandung

Triartanto, Y. 2010. Broadcasting Radio. Pustaka Book Publisher, Yogyakarta.

Wowor, C , J. 2013. Pengaruh Iklan Komersial di Radio Terhadap Perilaku

Konsumtif

Masyarakat Kelurahan Bahu Kota Manado. Jurnal: Vol 2. No 1. Universitas Sam Ratulangi. Manado

Wibowo, Setyo F. 2012. Pengaruh Iklan Televisi dan Harga terhadap Keputusan Pembelian. Jurnal Riset Manajemen Sains Indonesia.

Analisis Pengaruh Penggunaan Jasa Iklan Radio Terhadap Tingkat Pendapatam Usaha 